\title{
INTERRELATED ASPECTS OF RESIDENTIAL SUBURBANIZATION AND COLLECTIVE QUALITY OF LIFE: A CASE STUDY IN CZECH SUBURBS
}

Jaroslav Biolek, Ivan Andráško, Jiří Malý, Pavlína Zrůstová

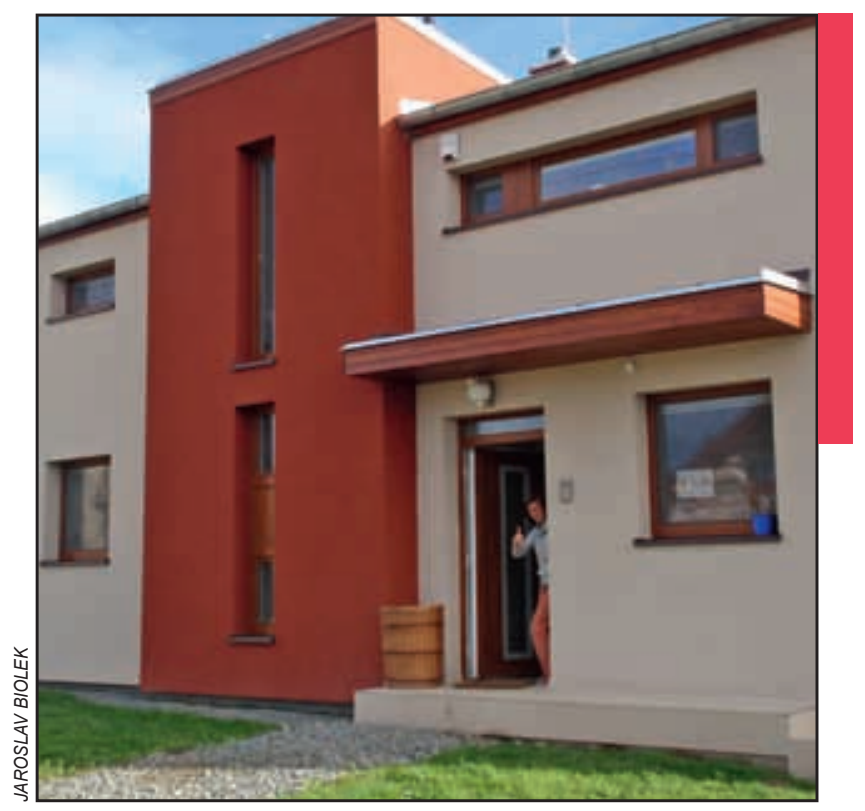

Suburban house and resident in the hinterland of Czech city Olomouc. 


\title{
Interrelated aspects of residential suburbanization and collective quality of life: A case study in Czech suburbs
}

\author{
DOI: http://dx.doi.org/10.3986/AGS.909 \\ UDC: $911.375 .1: 316.728(437.3)$ \\ COBISS: 1.01
}

\begin{abstract}
Most people moving to suburban municipalities seek to enhance their quality of life. However, residential suburbanization may contribute to spatial separation of the population and adversely affect the collective quality of life. This article focuses on socio-geographical aspects of quality of life in the context of suburbanization from a theoretical perspective and also based on a case study in the countryside around the Czech city of Olomouc. Due to the complex nature of this issue, a range of qualitatively oriented methods was applied in the municipalities most affected by residential suburbanization. The findings of the case study show that quality of life for people living in these suburbs is influenced by geographical conditions as well as relations within the community and residents' participation in public life in the municipality.
\end{abstract}

KEY WORDS: human geography, suburbanization, collective quality of life, community, suburbs of Olomouc, Czech Republic

The article was submitted for publication on September $17^{\text {th }}, 2014$.

\section{ADDRESSES:}

Jaroslav Biolek, M.Sc.

Department of Geography, Faculty of Science, Palacký University

17. listopadu 12, 771 46, Olomouc, Czech Republic

and

Department of Geography, Faculty of Science, Masaryk University

Kotlářská 2, 61137, Brno, Czech Republic

E-mail: jaroslavbiolek@gmail.com

\section{Ivan Andráško, Ph. D.}

Department of Geography, Faculty of Science, Palacký University 17. listopadu 12, 771 46, Olomouc, Czech Republic

and

Department of Geography, Faculty of Science, Masaryk University Kotlářská 2, 61137, Brno, Czech Republic

E-mail: geoganry@mail.muni.cz

\section{Jiří Malý, M.Sc.}

Department of Geography, Faculty of Science, Masaryk University Kotlářská 2, 61137, Brno, Czech Republic

E-mail: j.maly@mail.muni.cz

\section{Pavlína Zrůstová, M.Sc.}

Department of Geography, Faculty of Science, Masaryk University Kotlářská 2, 61137, Brno, Czech Republic

E-mail: pzrustova@seznam.cz 


\section{Introduction}

Suburbanization is often labeled the main process transforming the character of the landscape and the shape of municipalities in the countryside around cities in central Europe (e.g., Ravbar 1997; Kok 1999; Sýkora and Ouředníček 2001; Gašperič 2004; EEA 2006; Kontuly and Tammaru 2006; Couch et al. 2007; Krisjane and Berzins 2012). However, it is also a controversial phenomenon. Most people move to the suburbs following a dream to improve their quality of life by changing their housing and environment. Nevertheless, residential suburbanization may produce the opposite effect. New suburban residents may lose their social contacts and may not adapt to their new environment, resulting in deterioration of their overall quality of life (Jackson 1985; Fishman 1989; Baldassare 1992; Jensen \& Leven 1997; and, in the Czech context, Potočný 2006; Galčanová and Vacková 2008; Biolek and Andráško 2011).

In the Czech Republic there is also potential for the growth of spatial separation of people voluntarily moving to the suburbs (Brabec and Sýkora 2009), but the negative results of this process adversely affect the collective quality of life in these localities. Although suburbanization may contribute to social homogenization of parts of communities, at a higher level it instead lowers social cohesion and inclusion (Šafr, Bayer and Sedláčková 2008). The sense of belonging to a place of residence and social relationships in the municipality may thus be key circumstances that substantially influence quality of life (e.g., Harris and Larkham 1999; Cicognani et al. 2008). In addition to the impacts of a specific environment, it is especially important to pay attention to the extent and form of participation by newcomers and old residents (e.g., Baldassare 1992; Putnam 2001). This article also reflects these tendencies and offers a new view on socio-geographical links to quality of life in the suburbanization process, both from the theoretical perspective and based on applied research.

This article interprets selected findings of a case study on the collective quality of life in Czech suburbs on August 2012. The municipalities investigated - Hlušovice, Dolany, Velký Týnec, and Křelov-Břuchotín are some of the ones most affected by residential suburbanization in the countryside around the city of Olomouc (Biolek and Andráško 2012). Bearing in mind the complex nature of this issue, we applied a multiphase qualitatively oriented research design and carried out participant observation, mental mapping, and especially semi-structured interviews with local stakeholders and inhabitants. The outputs of the case study thus emphasize a broad spectrum of socio-geographical aspects of collective quality of life in relation to suburbanization, such as describing the influence of local planning on collective life, or how local schools foster social integration.

\section{Theoretical background}

Rather than offering an exhaustive definition of collective quality of life or a comprehensive conceptualization of this phenomenon, this section outlines perspectives that open the path to the research. Because there is a great range of theoretical concepts, the terminology used to discuss quality of life is often ambiguous and vague, especially when one seeks to overcome the dichotomy between the quality of life of an individual and that of a specific socio-geographical group of inhabitants (e.g., van Kamp etal. 2003; Phillips 2006). In a simplified manner, quality of life can be understood as a qualitative evaluation and interpretation of the life of a person or a certain group of people, which is a product of a person's or social group's mutually influential external and internal factors (Andráško 2008). Thereby, the key precondition of socio-geographical research on quality of life is understanding the mutual interaction between people and their environment (Pacione 2003; Andráško 2009).

According to many experts (e.g., Felce and Perry 1995; Bowling 1995; Massam 1999; Pacione 2003), for research purposes quality of life can be divided into partial domains, dimensions, or components (e.g., health aspects and influence of family). Nevertheless, the structuring of external and internal factors into partial domains and their expression by means of indicators may distance researchers from understanding mutually influential relations that create the nature of individual or collective quality of life. Instead of this conceptualization, we instead focus on the actors and, following a qualitatively oriented research design, we describe their relations that contribute to quality of life.

A first glance shows collectives of people living in suburban municipalities; that is, local communities related to a specific place of residence and defined geographically as neighborhoods (Wellman and 
Leighton 1979). However, can one speak about a local community anchored in a suburban municipality and perform research on quality of life in such a neighborhood? According to Wilkinson (1991), most people spend time where they live and become involved in most social interactions in such places. Inside such neighborhoods, social contacts take place in community interaction fields, or nodal integration points. However, Wellman and Leighton (1979) argue that a community defined as a network of social relations does not necessarily have to be bound to a particular place. The question is whether it is possible to speak about a united community in the instance of heterogeneous socio-geographical groups of suburban municipalities. In our opinion, there are instead various social groups or sub-communities of people connected by sociocultural interests (Fishman 1989; Baldassare 1992), as shown in this case study.

When studying community interaction, one must not forget a role of social institutions and organizations in municipalities, such as schools, preschools, sports clubs, cultural centers, or maternity centers. Lockwood (1999) argues these are the specific collective actors initiating social interactions and developing the social inclusion of new residents, especially in the suburbs. As demonstrated based on the examples, these institutions play a crucial role in local inhabitants' involvement in a municipality's sociocultural life.

These perspectives omit non-human factors (e.g., influence of the physical environment, infrastructure). The reduction of the research topic to human actors and their relations considerably limits the understanding of the collective quality of life. Inspired by actor-network theory (Latour 2005), we define the "collective" as all the actors with relevant involvement in the socio-geographical network of suburban municipalities. Therefore, elements of infrastructure and municipal facilities, houses, cars, and, of course, the mutual relations of these objects and people should also be included. For instance, interdependence between people and cars can be one of the most important relations transforming the environment and social life in the suburbs (e.g., Newman \& Kenworthy 1999).

Thereby, our research design is based on a socio-geographical approach to collective quality of life. Under these circumstances, it is necessary to interpret how people's lives are influenced by newly reconstructed infrastructure or regular cultural events in the municipality and, on the other hand, how the inhabitants themselves contribute to their organization.

\section{Research methodology}

The research was carried out in the municipalities of Hlušovice, Velký Týnec, Dolany, and Křelov-Břuchotín as a continuation of a survey that widely mapped the countryside around Olomouc in terms of the impacts of suburbanization on various life domains of local communities (Biolek and Andráško 2012). The main objectives of the research design were to capture the relations between inhabitants and environment in terms of suburbanization. In order to understand and interpret the facts that form quality of life and its perception, we used a qualitatively oriented research method.

The type of case study selected also reflected the need to describe specific aspects of suburbanization in various localities. The research was carried out in a flexible manner until the point of saturation; that is, until a sufficient amount of information was obtained that was necessary for a thorough description and interpretation of the case (Yin 1984). The various living environments in municipalities affected by suburbanization (in terms of the number of inhabitants, population structure, or building types) not only offered perspectives for comparison, but also increased the demands for synthesis and interpretation of qualitative data about the life of the local communities.

After the pre-research phase of participant observation and testing the interview methodology and mental maps in August 2012, we chose stakeholders in selected municipalities (mayors, representatives, organizers of cultural events) with a certain influence on political, social, and cultural affairs. Semi-structured interviews were recorded with these people regarding the perception of socio-spatial aspects of quality of life, social affairs in the municipality, interpersonal relationships, and relations to the local environment, all in the context of the suburbanization process. At the end of the semi-structured interviews, the informants could suggest other people involved in social affairs in the municipality for subsequent interviews (i.e., the snowballing method).

The next phase focused on citizens that did not participate in the previous phase. The informants were both old residents and newcomers (defined as those that had lived less than ten years in the municipality). The selection and contents of the questions were influenced by the duration of residence, relation to the 


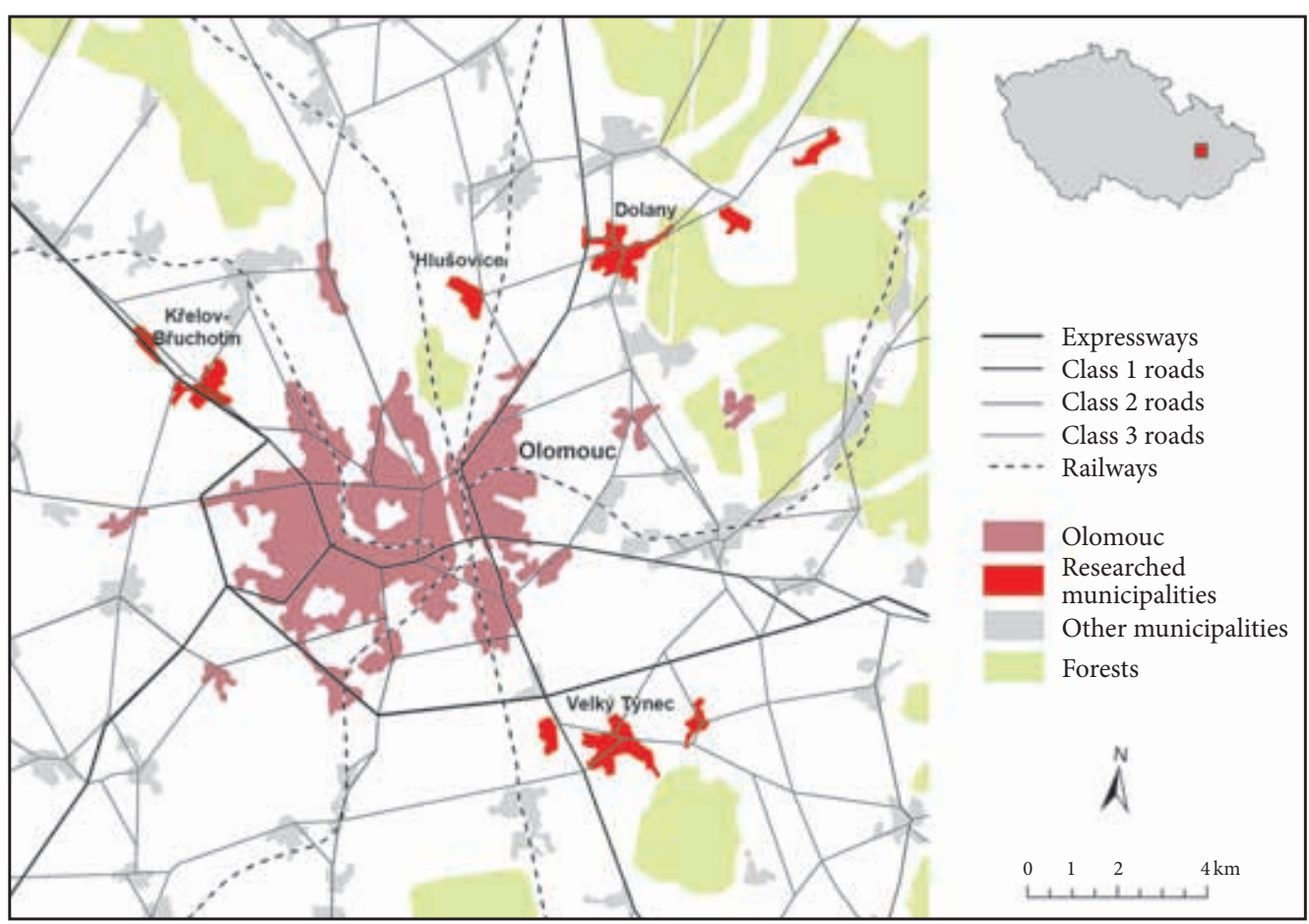

Figure 1: Location of the municipalities studied.

municipality and other inhabitants, and other factors. We first asked about satisfaction with housing and various life domains in the municipality and about informants' own definition of quality of life. Other questions were oriented toward community relationships or participation in social life in the municipality. After the semi-structured interviews (totaling eighty-two, or approximately twenty interviews per municipality), the informants were asked to sketch out their residence in the context of the neighborhood and its features. The sketches were deciphered and interpreted by using the various conceptual approaches of Lynch (1960), Appleyard (1973), or Tuan (1975). The last phase of the research was acquiring missing information by means of alternative methods (e.g., content analysis of local documents about social affairs), which complemented data from interviews and mental maps. All of the interviews were recorded and anonymized, and all of the data have been filed in the authors' archive.

The fieldwork was followed by an analytical phase in which it was necessary to decipher, operationalize, and sort the information. In the case study, we first applied an open coding method to analyze the transcribed interviews. Some information from the interviews was labeled using analytical codes with a precise description of data using research terms (e.g., history of housing construction in a given municipality, role of the pump effect or physical barriers, importance of sociocultural events, and contacts in preschools or schools) or by in vivo codes (e.g., descriptions such as »only place to sleep« or »a millionaire district«; Cloke et al. 2004). We thus generated a complex map of open codes in which we looked for semantic interrelations.

The codes on the map were systematically joined and categorized on the basis of the key attributes of collective quality of life in the context of the suburbanization process. We thus defined categories that represent and connect emergent thematic aspects of suburban collective life (housing construction and local planning, transportation and spending time in the municipality, physical barriers and social inclusion, social relations and conflicts between sub-communities) and then analyzed them. Similarly, in vivo codes were systematically incorporated into the categories (some of them were also used in the following section). The codes within the groups were semantically linked, and these connections were described with axial labels expressing various kinds of relationships (similarity, difference, contradiction, example or cause of 
another code). For instance, codes related to social inclusion and community interactions (such as social and cultural events, preschools, schools, or other nodal integration points) were linked together and, consequently, relations between them were interpreted according to factual transcriptions of the interviews (e.g., presence of physical barriers in closer municipalities in contrast to more distant ones, or the social inclusion function of social and cultural events for families with children but not for teenagers). In this phase, emphasis was mostly placed on differences between information from old residents and new residents (or sub-communities).

Finally, we sorted all of the semantic groups using thematic operationalization and synthesized them into relevant interpretable outputs based on our theoretical background. Regarding the collective quality of life in the suburbs, relevant information was selected according to the aims stated earlier in this article. Thus, core thematic groups of codes needed to interpret the collective quality of life were identified and systematically linked to approaches that were not only varied and specific, but especially to significant socio-geographical aspects of the suburban municipalities (following the line of interpretation from local planning and environmental aspects to barriers of social inclusion and nodal integration points between new residents and old residents).

\section{Case study findings}

The municipalities studied are located in the countryside around Olomouc, which is the largest city in central Moravia with a population of about 100,000. These municipalities were selected based on a previous analysis according to the indicators of migration and new home construction (Biolek and Andráško 2012). However, this case study more closely examines social relations in the municipality, the sense of belonging to the municipality, the extent to which residents participate, and other characteristics of the collective quality of life.

It is important to describe the development and forms of residential suburbanization in the municipalities investigated. The first municipality, Dolany, was affected by the earliest wave of suburbanization in the second half of the 1990s, whereas Hlušovice and Křelov-Břuchotín were affected shortly after 2000. At that time there were no land-use plans or they were obsolete, and therefore the municipalities could only regulate construction with great difficulty and construction work was quite chaotic. In most cases, the sale of building plots and construction were initiated by the plots owners and builders, and the construction work was not coordinated. The construction of infrastructure networks, for which builders themselves are responsible, was delayed or insufficient in many cases, especially in development projects. Among the municipalities selected, Velký Týnec is an exception. Housing construction started there in 2008, and the locations were established at the initiative of the municipality. Regulation by the municipality has also been more apparent than in other settlements. However, the construction of some projects is continuing in all the municipalities even though the local authorities are trying to limit further development or at least direct it to more favorable locations (e.g., into built-up areas).

An obvious negative environmental aspect of construction is the use of agricultural land (Kahn 2000). Especially in the vicinity of Olomouc, the area of fertile land is decreasing (Burian, Miřijovský and Macková 2011; Biolek and Andráško 2012). All of the municipalities are also in a non-flood area, which is a significant geographical factor influencing construction and in-migration. In all of the municipalities, there are newly built neighborhoods on the outskirts of the settlements. Another problem is deteriorating housing and abandonment of old houses in built-up areas of the municipality in contrast to the development of the outskirts, disturbing the rural character of the municipality. For financial reasons or simplicity, it is easier to build a house on a greenfield site instead of renovating an existing house (Harris and Larkham 1999).

Individual vehicular traffic is the prevailing type of transport between Olomouc and suburban municipalities. Many people have two or more cars, and so regular commuting certainly influences local people's participation in social affairs. Municipal residents with better accessibility to Olomouc (from Krrelov-Břuchotín) have greater motivation to go to Olomouc to take advantage of a wider variety of leisure activities. In this case, transport causes a "pump effect " and people therefore lose the motivation to participate in collective life.

Not only a high socioeconomic class in Olomouc is moving to suburban municipalities, but also other social groups from neighboring towns and villages, and therefore the socio-geographical structure of new- 


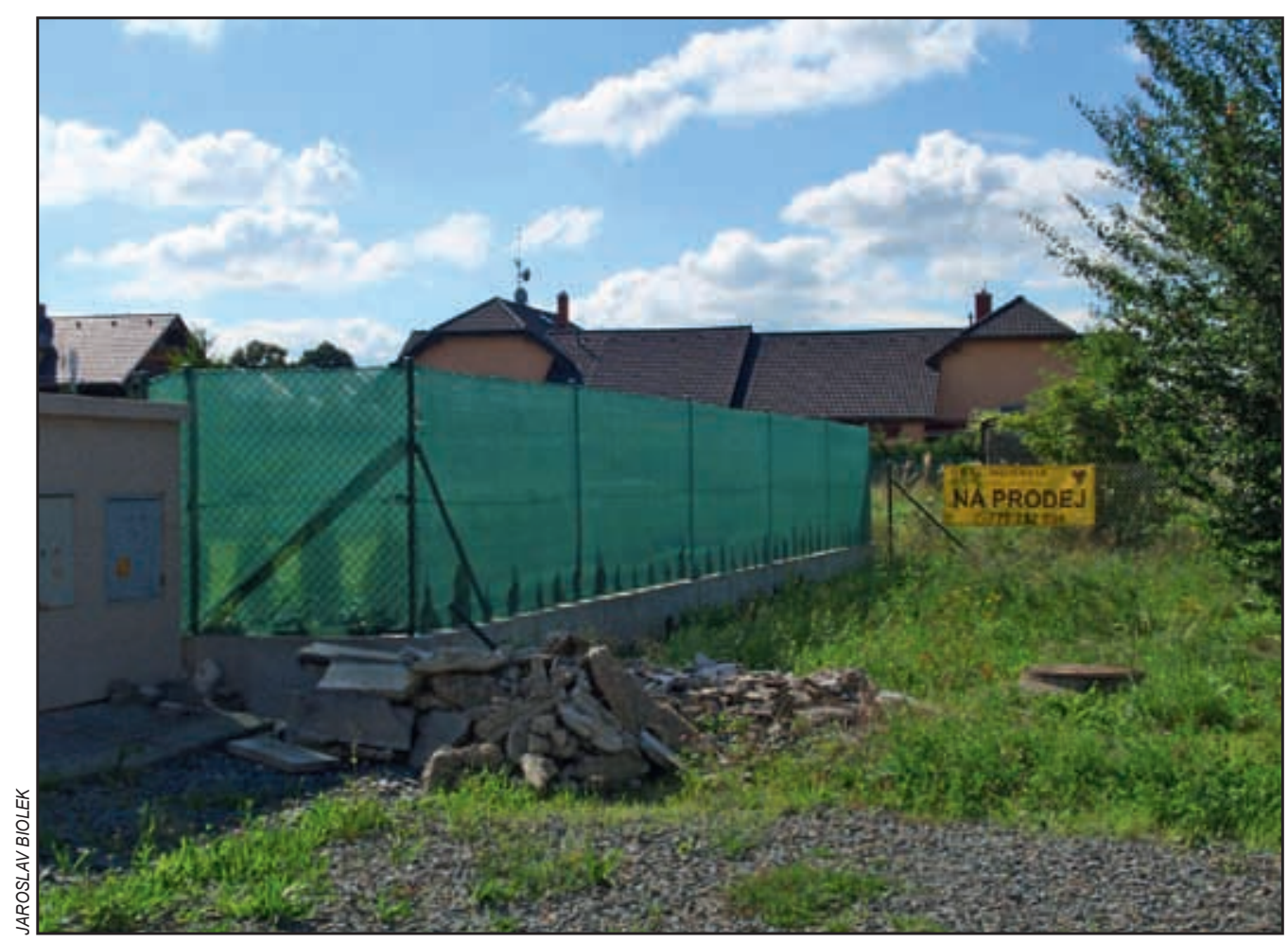

Figure 2: A detached house behind a high fence with unfinished infrastructure in Dolany.

comers is varied. Nevertheless, new buildings are characterized by the old residents as "a millionaire district « even though there are very few real millionaires and most newcomers buy their homes using a mortgage. The diversity of the local population also influences the level of social integration and inclusion (Raphael et al. 2001). The integration of newcomers into the local community increases over time and the old residents start to respect and accept them more. One respondent from Křelov-Břuchotín expressed the relationship between old residents and newcomers like this: »it takes ten years for you to stop being an unwanted newcomer and another five years to be considered a local." However, some newcomers have been living in the municipalities for more than ten years without integration and they only use their place of residence as a "place to sleep."

The case study shows that it may be difficult to overcome barriers between old residents and newcomers and to make contacts. Many new residents remain shut inside their houses and seldom engage in social interaction with the environment. The type and character of buildings also plays an important role; that is, people dwelling in houses behind high fences socialize less and have fewer contacts with neighbors than residents living in terraced houses. Although social differences partially fade away as a result of the relatively varied socio-geographical structure of the population in suburban municipalities, the character of buildings - and thus a different physical environment - emphasizes borderlines between residents.

As previous studies (Potočný 2006; Biolek and Andráško 2012) showed, rather than increasing social communication between these two groups and decreasing social cohesion in the municipality, an overall transformation of social relations prevails, forming new sub-communities (within the group of newcomers or between both groups). Most informants allege they have either neutral or slightly positive relations with the other group. Within the community of new residents, some new intimate relationships and firm social connections may also appear (depending on the character of built-up area). Especially in Hlušovice, it was obvious that newcomers are a more involved part of the population. They organize cultural and sports events and participate more in the social life of the municipality. 


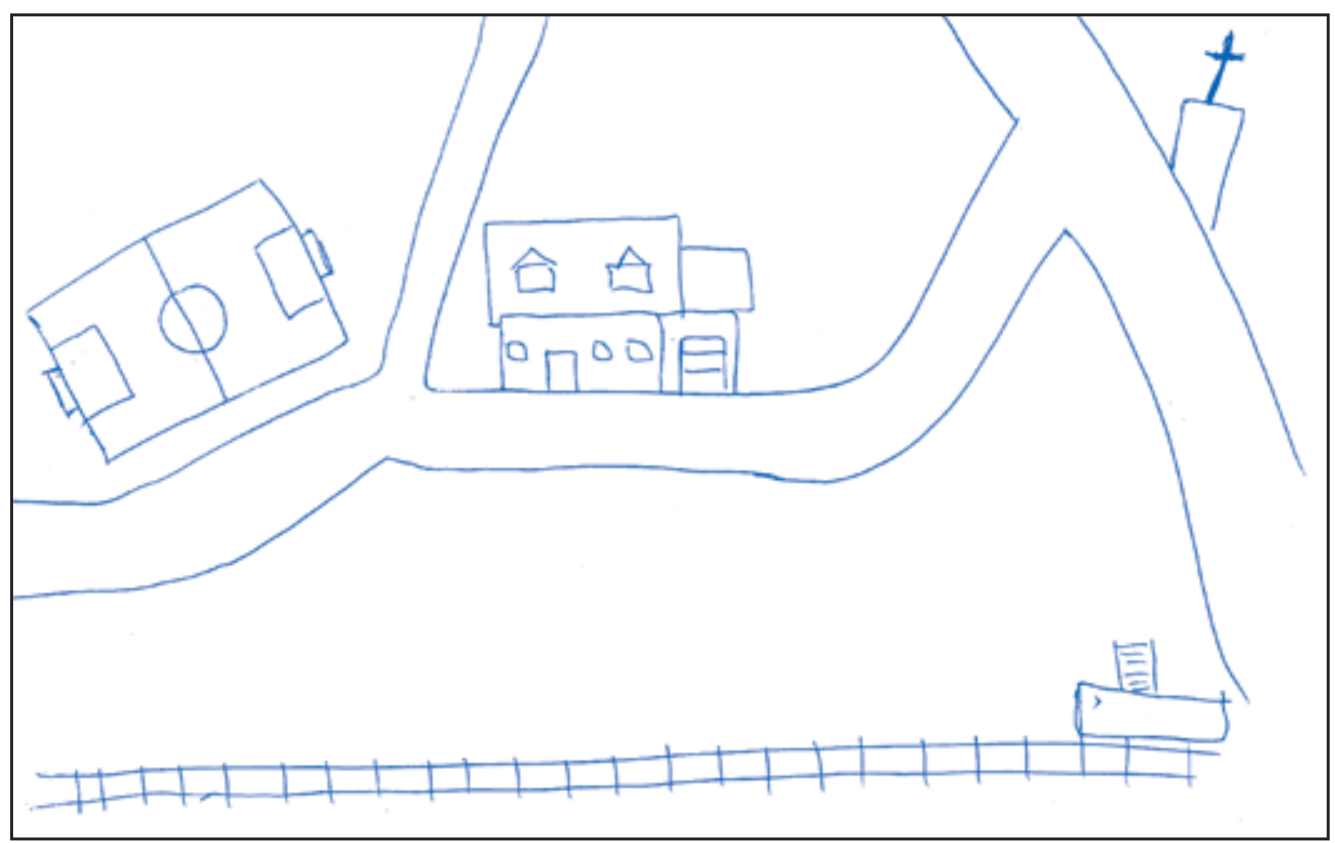

Figure 3: An example of the mental map of Hlušovice made by a newcomer.

Cultural, sports, and other social events are an important social bridge between newcomers and old residents. Social events in the selected suburbs can be viewed in terms of the main nodal integration points in which social inclusion of the municipality's inhabitants has developed (Wilkinson 1991). People in the selected municipalities are well aware of this, and by supporting cultural associations they attempt to provide a wide range of social events (dances, banquets, and other festivities). Social events are mostly adapted for parents with children as well as for young mothers. Those organized by children's clubs or women's clubs are the main events where people can make new contacts with other inhabitants and can overcome social barriers. On the other hand, for other social groups, especially for teenagers, the municipalities do not offer enough entertainment.

Intensification of social contacts occurs through of social events and through institutions for children (preschools and schools). Nevertheless, the growing number of children in the municipalities studied is creating a problem because of the insufficient capacity of preschools. Preschool management is forced to select children according to certain criteria, which may raise doubts or cause possible disputes among parts of the community. On the other hand, primary schools, which are supposed to foster social integration, are often not attended by newcomers' children. There are several reasons for this, from the practice of taking children to primary schools in Olomouc when commuting to the negative reputation of local schools. This limits the opportunity to make new contacts and for children and their parents to integrate.

It is easier for new residents to integrate and make new contacts in smaller municipalities because in larger settlements there are greater socio-spatial differences between old and new residents, or a more »depersonalized environment. " Therefore, the collective quality of life in these municipalities depends not only on the character and quality of social relations, but also on the size and structure of the community (Raphael et al. 2001) or on the type of built-up area with indirect influence (Rowland and Mitchell 2012).

\section{Conclusion and discussion}

It is difficult to incorporate different views on quality of life and create a cohesive picture to describe the collective quality of life of the residents of a certain locality in a complex way. However, this research reflected 
on these perspectives and interpreted the quality of life of residents in selected suburban municipalities with an emphasis on socio-spatial relations.

Although the municipalities studied are facing problems connected to social inactivity and socio-spatial separation, the newcomers have been gradually integrating. The main integration element is children and social events connected with them. During activities at various children's clubs and preschools, mothers that are newcomers and old residents make contacts and create social bonds. On the other hand, one of the obstacles to social inclusion in these municipalities is a low percentage of newcomers' children in local primary schools in contrast to the great demand for placement of children in preschools.

Regarding environmental aspects, most informants perceive their environment to be important; they consider suburban municipalities suitable for rearing children and the opportunity to spend time outdoors as a relevant factor for their quality of life. The character of built-up areas influences social contacts and relations in the community and consequently quality of life (Biolek and Andráško 2012). Although the inhabitants of the selected municipalities do not explicitly connect their quality of life with the sense of belonging to the place they live, they consider the development of necessary infrastructure, for example, to be the key factors for enhancing quality of life.

Although suburban residents' satisfaction with their current life depends on satisfying material needs, quality of life still depends on the quality of their socio-geographical environment (Pacione 2003). In other words, the collective quality of life of people that actively participate in their community may also positively affect their individual lives. On the other hand, if people distance themselves from social life, the impacts of collective factors are limited. Their quality of life is instead influenced by other factors (e.g., material and economic) and these people may not reach such a level of satisfaction with the environment as inhabitants in the first case (Fishman 1989; Putnam 2001). Thus, the interrelation of collective and individual quality of life in suburban municipalities can partially be explained by the principle of complementarity (Andráško 2010).

This study has also shown that geography has an effect on relations in a socio-geographical environment and has an impact on quality of life in suburban municipalities. This study should initiate a discussion about research on collective quality of life (and not only in suburbs in central Europe) as well as the application of qualitatively oriented methodology.

ACKNOWLEDGEMENTS: This study was funded by the following project of the Czech Science Foundation: »Urban and Suburban Quality of Life: A Geographical Perspective« (P404/11/1811). The authors are grateful for this support.

\section{References}

Andráško, I. 2010: Potenciál priestorovej komplementarity - konceptualizácia a aplikácia (prípadová štúdia okresu Pezinok). Časoprostorové změny regionálních a krajinných struktur. Brno.

Andráško, I. 2009: The role and status of geography in the quality of life research. Geodny Liberec 2008: sborník př́spěvků. Liberec.

Andráško, I. 2008: Hlavné komponenty spokojnosti s kvalitou životných podmienok v mestských štvrtiach Bratislavy. Změny regionálních struktur České republiky a Slovenské republiky. Brno.

Appleyard, D. 1973: Notes on urban perception and knowledge. Image and environment: Cognitive mapping and spatial behaviour. London.

Baldassare, M. 1992: Suburban communities. Annual review of sociology 18-1. DOI: http://dx.doi.org/ 10.1146/annurev.so.18.080192.002355

Biolek, J., Andráško, I. 2012: Rezidenční suburbanizace v zázemí největších měst Olomouckého kraje. Časoprostorové změny regionálních struktur ČR a SR. Brno.

Biolek, J., Andráško, I. 2011: Rezidenční suburbanizace v ČR a její společenské dopady. Časovo-priestorové aspekty regionálnych štruktúr ČR a SR. Bratislava.

Bowling, A. 1995: What things are important in people's lives? A survey of the public judgements to inform scales of health related quality of life. Social science \& medicine 41-10. DOI: http://dx.doi.org/10.1016/ 0277-9536(95)00113-L 
Brabec, T., Sýkora L. 2009: Gated communities in Prague. Gated and guarded housing in Eastern Europe. Forum IFL 11. Leipzig.

Burian, J., Miřijovský, J., Macková, M. 2011: Suburbanizace Olomouce - hodnocení pomocí analýzy statistický dat. Urbanismus a územní rozvoj 14-5.

Cicognani, E. Pirini, C., Keyes, C., Joshanloo, M., Rostami, R., Nosratabadi, M. 2008: Social participation, sense of community and social well-being: A study of American, Italian and Iranian University students. Social indicators research 89-1. DOI: http://dx.doi.org/10.1007/s11205-007-9222-3

Cloke, P. Cook, I., Crang, P., Goodwin, M., Painter, J., Philo, C. 2004: Practising human geography. London.

Couch, Ch. Petschel-Held, G., Leontidou, L. 2007: Urban sprawl in Europe. Landscapes, land-change and policy. Oxford.

EEA 2006: Urban sprawl in Europe: The ignored challenge. Copenhagen.

Felce, D., Perry, J. 1995: Quality of life. Its definition and measurement. Research in development disabilities 16-1. DOI: http://dx.doi.org/10.1016/0891-4222(94)00028-8

Fishman, R. 1989: Bourgeois utopias: The rise and fall of suburbia. New York.

Galčanová, L., Vacková, B. 2008: Rezidenční suburbanizace v postkomunistické České republice, její kořeny, tradice a současnost. IVRIS Papers 3-2.

Gašperič, P. 2004: The expansion of Ljubljana onto the Ljubljansko Barje Moor. Acta geographica Slovenica 44-2. DOI: http://dx.doi.org/10.3986/AGS44201

Harris, R., Larkham, P. J. 1999: Changing suburbs. Foundation, form and function. London.

Jackson, K. T. 1985: Crabgrass frontier: the suburbanization of the United States. Oxford.

Jensen, M. J., Leven, C. L. 1997: Quality of life in central cities and suburbs. Annals of regional science 31-4. DOI: http://dx.doi.org/10.1007/s001680050057

Kok, H. 1999: Migration from the city to the countryside in Hungary and Poland. Geojournal 49-1. DOI: http://dx.doi.org/10.1023/A:1007092228633

Kahn, M.E. 2000: Environmental impact of suburbanization. Journal of policy analysis and management 19-4. DOI: http://dx.doi.org/10.1002/1520-6688(200023)19:4<569::AID-PAM3>3.0.CO;2-P

Kontuly, T., Tammaru, T. 2006: Population subgroups responsible for new urbanisation and suburbanisation in Estonia. European urban and regional studies 13-4. DOI: http://dx.doi.org/10.1177/0969776406065435

Krisjane Z., Berzins, M. 2012: Post-socialist urban trends: new patterns and motivations for migration in the suburban areas of Rìga, Latvia. Urban studies 49-2. DOI: http://dx.doi.org/10.1177/0042098011402232

Latour, B. 2005: Reassembling the social: an introduction to actor-network-theory. Oxford.

Lynch, K. 1960: The image of the city. Cambridge.

Massam, B. H. 1999: The Classification of quality of life using multi-criteria analysis. Journal of geographic information and decision analysis 3-2. DOI: http://dx.doi.org/10.1016/S0305-9006(02)00023-5

Pacione, M. 2003: Urban environmental quality and human well-being - a social geographical perspective. Landscape and urban planning 65, 1-2. DOI: http://dx.doi.org/10.1016/S0169-2046(02)00234-7

Phillips, D. 2006: Quality of life. Concept, policy and practice. Oxon.

Potočný, T. 2006: Lidé na okraji. Př́padová studie satelitního městečka. IVRIS Papers 1.

Putnam, R. 2001: Bowling alone: the collapse and revival of American community. New York.

Newman, P., Kenworthy, J. 1999: Sustainability and cities: Overcoming automobile dependence. Washington, DC.

Raphael, D., Renwick, R., Brown, I., Steinmetz, B., Sehdev, H., Phillips, S. 2001: Making the links between community structure and individual well-being: community quality of life in Riverdale, Toronto, Canada. Health \& Place 7-3. DOI: http://dx.doi.org/10.1016/S1353-8292(01)00008-9

Ravbar, M. 1997: Slovene cities and suburbs in transformation. Geografski zbornik 37.

Rowland, J., Mitchell, C. 2012: The quality of life in cities: the twenty-first century suburb. Proceedings of The Institution of Civil Engineers: urban design and planning 165-3. DOI: http://dx.doi.org/10.1680/udap.11.00015

Sýkora L., Ouředníček, M. 2001: Sprawling post-communist metropolis: commercial and residential suburbanisation in Prague and Brno, the Czech Republic. Internet: http://www.natur.cuni.cz/ slamak/ gacr/selma.pdf (19.6. 2014). DOI: http://dx.doi.org/10.1007/978-1-4020-5762-5_8

Šafr, J., Bayer, I., Sedláčková, M. 2008: Sociální koheze. Teorie, koncepty a analytická východiska. Sociologický časopis 44-2.

Tuan, Y.-F. 1975: Images and mental maps. Annals of the Association of American geographers 65-2. DOI: http://dx.doi.org/10.1111/j.1467-8306.1975.tb01031.x 
Van Kamp, I. Leidelmeijer, K., Marsman, G., de Hollander, A. 2003: Urban environmental quality and human well-being. Towards a conceptual framework and demarcation of concepts; a literature study. Landscape and urban planning 65, 1-2. DOI: http://dx.doi.org/10.1016/S0169-2046(02)00232-3

Wellman, B., Leighton, B. 1979: Networks, neighborhoods, and communities: approaches to the study of the community question. Urban affairs review 14-3. DOI: http://dx.doi.org/10.1177/107808747901400305 Wilkinson, K. P. 1991: The community in rural America. London.

Yin, R. 1984: Case study research: design and methods. Newbury Park. 